\title{
Formation of natural gypsum megacrystals in Naica, Mexico
}

\author{
Juan Manuel García-Ruiz* Instituto Andaluz de Ciencias de la Tierra, Consejo Superior de Investigaciones Científicas- \\ Universidad de Granada, Campus Fuentenueva, E-18002 Granada, Spain \\ Roberto Villasuso Compañía Peñoles, Unidad Naica, Naica, Chihuahua, Mexico \\ Carlos Ayora Institut de Ciències de la Terra Jaume Almera, Consejo Superior de Investigaciones Científicas, \\ Lluis Solé Sabarís s/n, E-08028 Barcelona, Spain \\ Angels Canals Departament de Cristal.lografia, Mineralogia i Dipòsits Minerals, Universitat de Barcelona, \\ Martí Franquès s/n, E-08028 Barcelona, Spain \\ Fermín Otálora Instituto Andaluz de Ciencias de la Tierra, Consejo Superior de Investigaciones Científicas- \\ Universidad de Granada, Campus Fuentenueva, E-18002 Granada, Spain
}

\begin{abstract}
Exploration in the Naica mine (Chihuahua, Mexico) recently unveiled several caves containing giant, faceted, and transparent single crystals of gypsum $\left(\mathrm{CaSO}_{4} \cdot 2 \mathrm{H}_{2} \mathrm{O}\right)$ as long as $11 \mathrm{~m}$. These large crystals form at very low supersaturation. The problem is to explain how proper geochemical conditions can be sustained for a long time without large fluctuations that would trigger substantial nucleation. Fluid inclusion analyses show that the crystals grew from low-salinity solutions at a temperature of $\sim 54{ }^{\circ} \mathrm{C}$, slightly below the one at which the solubility of anhydrite equals that of gypsum. Sulfur and oxygen isotopic compositions of gypsum crystals are compatible with growth from solutions resulting from dissolution of anhydrite previously precipitated during late hydrothermal mineralization, suggesting that these megacrystals formed by a self-feeding mechanism driven by a solution-mediated, anhydrite-gypsum phase transition. Nucleation kinetics calculations based on laboratory data show that this mechanism can account for the formation of these giant crystals, yet only when operating within the very narrow range of temperature identified by our fluid inclusion study. These singular conditions create a mineral wonderland, a site of scientific interest, and an extraordinary phenomenon worthy of preservation.
\end{abstract}

Keywords: gypsum, crystallization, mineral growth, anhydrite, Naica mine, nucleation.

\section{GEOLOGIC SETTING}

The Naica mine is located on the northern side of the Sierra de Naica, $112 \mathrm{~km}$ SE of Chihuahua city in northern Mexico. It constitutes one of the most important lead and silver deposits in the world. The area is dominated by a $12-\mathrm{km}$-long, 7-km-wide dome structure oriented NW-SE, standing out from an extensive alluvial plain. The Naica mining district is entirely formed by sedimentary rocks, consisting of a sequence of Albian limestones with some lutitic interbeddings overlying an Aptian evaporitic sequence that has been found in the surrounding region, but not in the mining district. The sedimentary rocks are intruded by Tertiary acidic dikes dated as 26.2 and 25.9 Ma (Megaw et al., 1988). An igneous intrusion $4 \mathrm{~km}$ south of the Naica mine at a depth between 2 and $5 \mathrm{~km}$ was revealed by magnetometric studies.

The hydrothermal fluid circulation associated with the Tertiary dikes formed the Ag-Pb-Zn deposits (Lang, 1995). These deposits display chimney and manto shapes and developed in the dikes and in the enclosing carbonates, which appear to be intensively transformed to calc-silicates. A set of faults acts as the main structural control on the mineralization; Gibraltar, Montaña, and Naica are the most important (Fig. 1). The ore assemblage comprises pyrite-pyrrhotite, sphalerite, galena, and chalcopyrite, and formed from high-temperature hypersaline brines, according to published fluid inclusion data (Erwood et al., 1979; Lang, 1995).

\footnotetext{
*E-mail: jmgruiz@ugr.es.
}

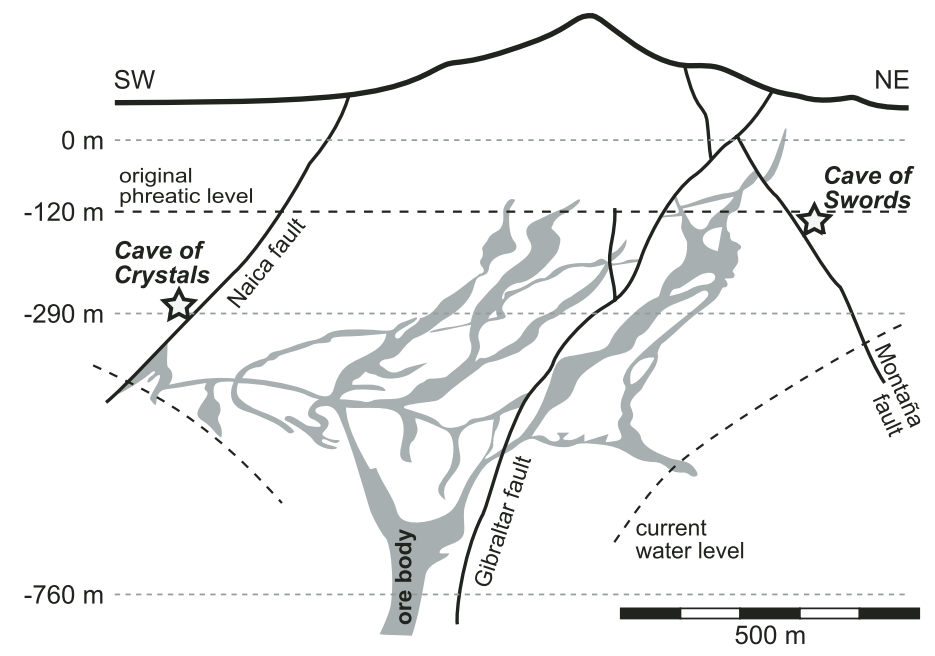

Figure 1. Cross section of Naica mine. Mine exploits hydrothermal $\mathrm{Pb}-\mathrm{Zn}-\mathrm{Ag}$ deposit with irregular manto and pipe morphologies entirely enclosed in subhorizontally dipping carbonates (not represented for simplicity). Cavities of gypsum crystals are located in carbonates close to main and secondary faults. Galleries have been excavated down to $-760 \mathrm{~m}$, requiring average pumping rate of $55 \mathrm{~m}^{3} / \mathrm{min}$ to depress groundwater to $-580 \mathrm{~m}$ with respect to phreatic level located at $\mathbf{- 1 2 0} \mathrm{m}$; Naica and Gibraltar faults act as main drains.

During the late hydrothermal stage, sulfuric acid formed by oxidation of the underlying sulfides, and this reacted with limestone to form calciumsulfate-rich waters that precipitated the anhydrite. Anhydrite occurs massively in Naica at all levels below $-240 \mathrm{~m}$. Late quartz-calcite-anhydrite veins cut the ore (Stone, 1959).

\section{GIANT SELENITE CRYSTALS}

Since early in the twentieth century, the excavation of new galleries and tunnels at the Naica mine has occasionally led to the discovery of cavities and caves containing meter-sized crystals of selenite, the colorless crystalline variety of gypsum. The caves are always located near fractures and their walls are covered by a red coating of calcite and celestite with minor amounts of iron oxide, montmorillonite, chlorite, and illite. Until 2000, the most famous of these caves was the Cueva de las Espadas (Cave of Swords), so named because of meter-sized selenite crystals (described by Foshag, 1927); that year several caves were discovered at the $-290 \mathrm{~m}$ level in secondary faults associated with the Naica fault (Fig. 1). One of these caves, the Cueva de los Cristales (Cave of the Crystals), contains selenite crystals as long as $11 \mathrm{~m}$ and as thick as $1 \mathrm{~m}$, much larger than any gypsum crystal previously reported (Foshag, 1927; Palache, 1932; Rickwood, 1981; García-Guinea et al., 2002). In addition, at that depth the impact of muddy, oxygen-enriched waters is very unlikely, and consequently the gypsum crystals contain very few solid inclusions of iron and 
manganese oxides, and are almost transparent, increasing their beauty and singularity. While several hypotheses have been suggested for the origin of these crystals, to date none of them has been thoroughly investigated (Marín Herrera et al., 2006).

The walls of the Cueva de los Cristales and particularly the floor are sprinkled with blocky single crystals that in some cases cluster to form parallel aggregates (see GSA Data Repository Fig. DR6 ${ }^{1}$ ). Rather than having the characteristic platy or tabular habit of gypsum crystals, they are euhedral, displaying well-developed $\{010\},\{1 \mathrm{k} 0\}$, and $\{-111\}$ forms (Fig. DR2; see footnote 1). The $\{010\}$ pinacoid is less developed than in the usual growth morphology of gypsum crystals. The $\{1 \mathrm{k} 0\}$ prism appears as striated surfaces made of segments of prismatic forms with $\mathrm{k}=2,4$, or 6 , as shown by laser reflection goniometry and scanning electron microscopy (Figs. DR3 and DR4 and Table DR1). The resulting nonsingular face has an orientation close to $\{140\}$.

Giant elongate selenite crystals grow from some of these groups of blocky crystals or directly from the floor, and some cross the cave from side to side (Fig. 2). Most of these crystals are $6 \mathrm{~m}$ long and several of them reach $10 \mathrm{~m}$. Consequently, the miners correctly term them vigas, or beams, instead of swords. In addition to the aspect ratio, there is only one morphological difference between the beams and the blocky crystals, i.e., the $\{010\}$ pinacoid faces of beams disappear in most cases. The crystalline beams are elongated in the direction of the $\mathrm{c}$ axis, defined by huge prismatic $\{1 \mathrm{k} 0\}$ faces and capped by $\{-111\}$ prisms (Fig. DR5). The density of crystals in the cave is very small (Fig. 2), creating a natural scenario of unparalleled beauty, and is critical to explain its formation, because this can only result from an extremely low nucleation rate for the entire history of the crystal growth. This must be the first boundary condition for any genetic model.

\section{GEOCHEMICAL CONDITIONS}

Gypsum is slightly soluble in water $\left(13.78 \times 10^{-3} \mathrm{~mol} \mathrm{~L}^{-1}\right.$ at $25^{\circ} \mathrm{C}$ and atmospheric pressure) (Partridge and White, 1929). Its solubility shows a positive dependence on temperature in cool waters, reaching a maximum at $\sim 58{ }^{\circ} \mathrm{C}$ and then decreasing (Posnjak, 1938). The solubility of gypsum also has a positive variation with salinity, but the temperature of maximum solubility near $58{ }^{\circ} \mathrm{C}$ does not change significantly (see the section "Nucleation and Growth of the Megacrystals," below). At atmospheric pressure, anhydrite is the stable thermodynamic phase at temperatures hotter than 56-58 ${ }^{\circ} \mathrm{C}$ (Hardie, 1967; Blount and Dickson, 1973), but below this temperature anhydrite becomes unstable with respect to gypsum.

The mine area is still a thermal anomaly: water samples collected at different times and mine locations show that the groundwater is $\sim 53{ }^{\circ} \mathrm{C}$ in the deep levels of the mine (Table DR4; see footnote 1), although temperatures as high as $59{ }^{\circ} \mathrm{C}$ have been measured by miners. Cooling of the system and contribution of meteoric waters yield sulfate- and carbonaterich water with a temperature in the range of $48-59{ }^{\circ} \mathrm{C}$, and a neutral to slightly basic $\mathrm{pH}(7.0-7.8)$, like the one today. According to their oxygen and deuterium isotopic values (Table DR3), present-day waters have a meteoric origin with more than $50 \mathrm{yr}$ of residence time in the aquifer, as indicated by the lack of tritium.

Upon cooling of the Naica district, hydrothermal anhydrite produced during the late stage of the formation of the ore deposit became unstable and dissolved, thus explaining the high content of sulfate anions in the present-day waters. The dissolution of anhydrite below $58{ }^{\circ} \mathrm{C}$ supplies $\mathrm{Ca}$ and $\mathrm{SO}_{4}$, thus keeping the water slightly supersaturated in gypsum and

${ }^{\text {I} G S A ~ D a t a ~ R e p o s i t o r y ~ i t e m ~ 2007080, ~ F i g u r e s ~ D R 1-D R 11, ~ a n d ~ T a b l e s ~ D R 1 ~}$ and DR2 (data sets, photos, and experimental details), is available online at www. geosociety.org/pubs/ft2007.htm, or on request from editing@geosociety.org or Documents Secretary, GSA, P.O. Box 9140, Boulder, CO 80301, USA.

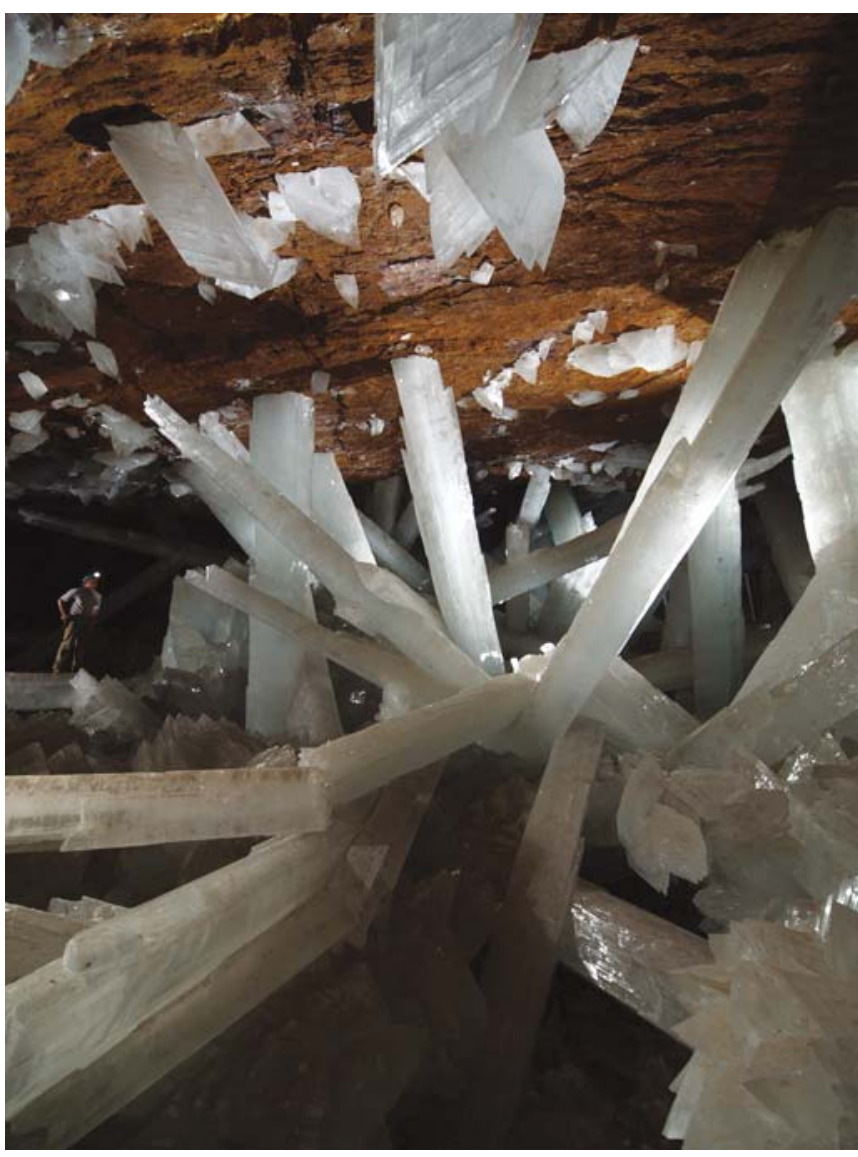

Figure 2. View of Cave of Crystals showing characteristic moonlight luster for which gypsum crystals are named (i.e., selenite). Two crystal morphologies include blocky crystals displaying prisms $\{1 \mathrm{k} 0\}$ and $\{-111\}$, and pinacoid $\{010\}$ and beams, which are crystals elongated along $c$ axis displaying only prismatic crystal faces. Note that population of crystals is much lower in ceiling of cave than on floor. For very long waiting time for nucleation, this gradation is due to a density layering of the solution filling cave (Turner, 1985), which increases the probability of nucleation from the solution located in lower part of cavern.

promoting its crystallization. Examples of this transition are also observed at a microscopic scale in some anhydrite masses close to the Cave of the Crystals (Fig. DR11). Supersaturation values $\left(S=\mathrm{c} / \mathrm{c}_{\mathrm{e}}\right.$, where $\mathrm{c}$ is the actual concentration and $c_{e}$ is the equilibrium concentration for a given temperature and salinity) calculated with the speciation code PHREEQC (Parkhurst and Appelo, 2003) for present-day waters yield values slightly supersaturated for gypsum and undersaturated for anhydrite. Such a small difference between the solubility of gypsum and anhydrite slightly below $58{ }^{\circ} \mathrm{C}$ is therefore a continuous source of calcium and sulfate ions in the Naica area and provides a very stable mechanism to constantly maintain the crystallizing system close to equilibrium. This is the mechanism we propose for the formation of the selenite megacrystals of Naica. To check this hypothesis, geochemical evidence is required to prove that selenite crystals grew from low-salinity solutions and that these solutions were produced by dissolution of anhydrite.

The salinity of the liquid from which selenite crystals grew was characterized by measuring the melting temperatures of ice in 33 selected fluid inclusions that contained liquid and vapor phases at room temperature (Fig. DR9 and Table DR2). The gypsum crystals contain very scarce fluid inclusions. Primary fluid inclusions parallel to crystal faces forming growth bands were selected (Fig. DR7). Measured tem- 
peratures of ice melting show a maximum at $-0.1{ }^{\circ} \mathrm{C}$ and a lower limit at $-1.1^{\circ} \mathrm{C}$. This range of temperatures indicates a low-salinity fluid $(0.17$ mass\% equivalent $\mathrm{NaCl}$ typical and 1.9 mass\% equivalent $\mathrm{NaCl}$ maximum) compatible with today's meteoric and mine waters (Bodnar, 1993; Bakker, 2003). That means that the original high-salinity, sulfur-rich, acidic magmatic fluids (Lang, 1995; Erwood et al., 1979) that caused the skarn formation had practically lost their salinity by the time the gypsum crystals grew. The dispersion of ice melting temperatures within an inclusion band is the same order of magnitude as the variations along the whole set of samples, and therefore no significant salinity variation with crystal growth can be established.

To check for the origin of the solutions, several samples of anhydrite and gypsum from different locations in the mine were collected for stable isotope analysis. The $\delta^{34} \mathrm{~S}$ and $\delta^{18} \mathrm{O}$ values of two gypsum samples from the Cave of the Crystals show no variation, despite the differing habit of the crystals (beams or blocky), with a $\delta^{34} \mathrm{~S}$ of $16.9 \%$ and $\delta^{18} \mathrm{O}$ of $17.6 \%$. As shown in Figure 3, the isotopic values of these gypsum crystals are consistent with their formation from waters with dissolved sulfate similar to those found in present-day groundwater collected at the -530 level. The isotopic values of sulfate dissolved in the water can be explained by mixing of sulfates from the dissolution of anhydrite at different locations of the mine: those from the ore deposit area (samples 23, 24, 25, and 34 in Table DR3) and those from upper levels in the mine (samples 04 and 21). Furthermore, these values, along with the absence of alunite and kaolinite minerals, eliminate a sulfuric speleogenesis mechanism (Polyak and Güven, 1996).

Additional evidence for the dissolution of anhydrite is the presence of celestite, a strontium sulfate found with clays and iron oxide in a thin layer coating the walls of the Cave of the Crystals. It has been demonstrated that the anhydrite structure can host more strontium than gypsum structure (Butler, 1973). Therefore, the celestite crystals likely result from the excess of strontium hosted in the dissolving anhydrite with respect to crystallizing gypsum (Table DR4).

\section{NUCLEATION AND GROWTH OF THE MEGACRYSTALS}

Geochemical evidence shows that close-to-equilibrium dissolution of anhydrite and crystallization of gypsum under the conditions of the Cave of Crystals can explain the origin of these giant crystals. The question remains if these values can also explain the low number of crystals observed, and as a consequence, the final size reached by each of them. The question is therefore how much cooling the system may have undergone to avoid the massive nucleation that would have packed the caves with a large number of smaller crystals. Classical crystal growth theory shows that the nucleation rate, $J$, is described by the equation:

$$
J=\mathrm{A} \exp -\frac{16 \pi \gamma^{3} v^{2}}{3 \mathrm{k}^{3} T^{3} \ln ^{2} S},
$$

where $\gamma$ is the crystal-liquid interfacial tension, $v$ is the molecular volume, $\mathrm{k}$ is the Boltzmann constant, $T$ is the absolute temperature, and $\mathrm{A}$ is a pre-exponential factor that can be considered constant in this discussion (Mullin, 1993). As the nucleation rate $J$ varies with the second power of the logarithm of supersaturation $S$, low values of $J$ mean that supersaturation was kept in the metastable zone and very close to equilibrium for the history of crystallization in the cave. Because the induction time $t_{\text {ind }}$ (time to induce formation of detectable crystals) for nucleation is inversely proportional to $J$, the equation can be written as a relationship:

$$
\ln t_{\text {ind }} \propto \frac{\gamma^{3}}{T^{3} \log ^{2} S} .
$$

Using experimental data available from gypsum nucleation studies (He et al., 1994; Lancia et al., 1999), we calculated (for both homogeneous and heterogeneous nucleation) the induction time for three salinities: calcium-

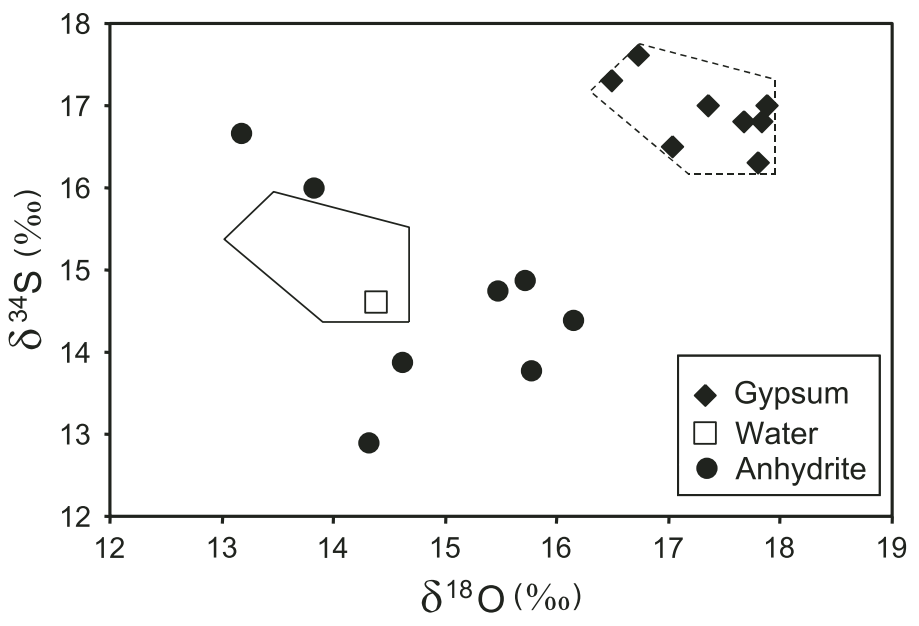

Figure 3. Isotope composition of sulfate molecules in gypsum, anhydrite, and water collected at Naica mine. Polygonal surface enveloping the isotope composition of water from which the gypsum crystals grew is obtained by subtracting from the gypsum values the enrichment factor of $1.65 \%$ for sulfur and $3.3 \%$ for oxygen (Thode and Monster, 1965).

sulfate and water molecules (labeled 0 ), salinity values (in terms of $\mathrm{Na}, \mathrm{Cl}$, and $\mathrm{Mg}$ concentrations) identical to those found in Naica waters (labeled 1), and twice these concentrations (labeled 2). Solubility values calculated with PHREEQC (Parkhurst and Appelo, 2003) were used to compute the supersaturation values and nucleation induction times plotted in Figure 4B. For any geological reservoir where crystallization occurs, heterogeneous nucleation is unavoidable because it requires lower critical supersaturation values to surpass the nucleation barrier. As shown in Figure 4B, the induction time for heterogeneous nucleation is thousands of years for temperatures of $47-48{ }^{\circ} \mathrm{C}$. For any temperature below $44-45^{\circ} \mathrm{C}$, we found a very large probability for nucleation within a time scale of months or days, inconsistent with the small number of crystals found in the caves.

To support the proposed mechanism, it is mandatory that the temperature during crystal growth is within the given range. We have used fluid inclusions to check this. Homogenization temperature $\left(T_{\mathrm{h}}\right)$ data from 31 fluid inclusions show values between $46{ }^{\circ} \mathrm{C}$ and $60{ }^{\circ} \mathrm{C}$ with a maximum of $\sim 54 \pm 1{ }^{\circ} \mathrm{C}$ (Fig. 4C; Table DR2 [see footnote 1]). According to the proposed mechanism, this implies that most of the crystallization process took place at a temperature for which $t_{\text {ind }}$ is longer than 1 m.y. (Fig. 4B). These close-to-equilibrium conditions were evidently maintained for a long time with some episodes of cessation of growth, as suggested by the occasional solid inclusions of manganese and iron oxihydroxides on $\{1 \mathrm{k} 0\}$ and $\{-111\}$ growth fronts. Eventually, as indicated by lower values of $T_{\mathrm{h}}$ down to $47{ }^{\circ} \mathrm{C}$, the system cooled due to a stronger influence of meteoric waters; the typical time for nucleation was thousands of years. It follows from this mechanism that caves such as the Cave of the Swords (Foshag, 1927) that are located closer to the surface had lower temperatures and are therefore filled with large numbers of smaller crystals (Fig. 1; Fig. DR1).

\section{CONCLUSION}

We offer an original explanation for the formation of large selenite crystals based on a self-feeding mechanism driven by solution-mediated anhydrite-gypsum phase transition at a temperature slightly below the gypsum-anhydrite equilibrium temperature. This explanation is supported by the following evidence. (1) Anhydrite was readily available from the late hydrothermal stage after the ore mineralization. (2) Temperature during the growth of the crystals was kept slightly below $58^{\circ} \mathrm{C}$, the value at 


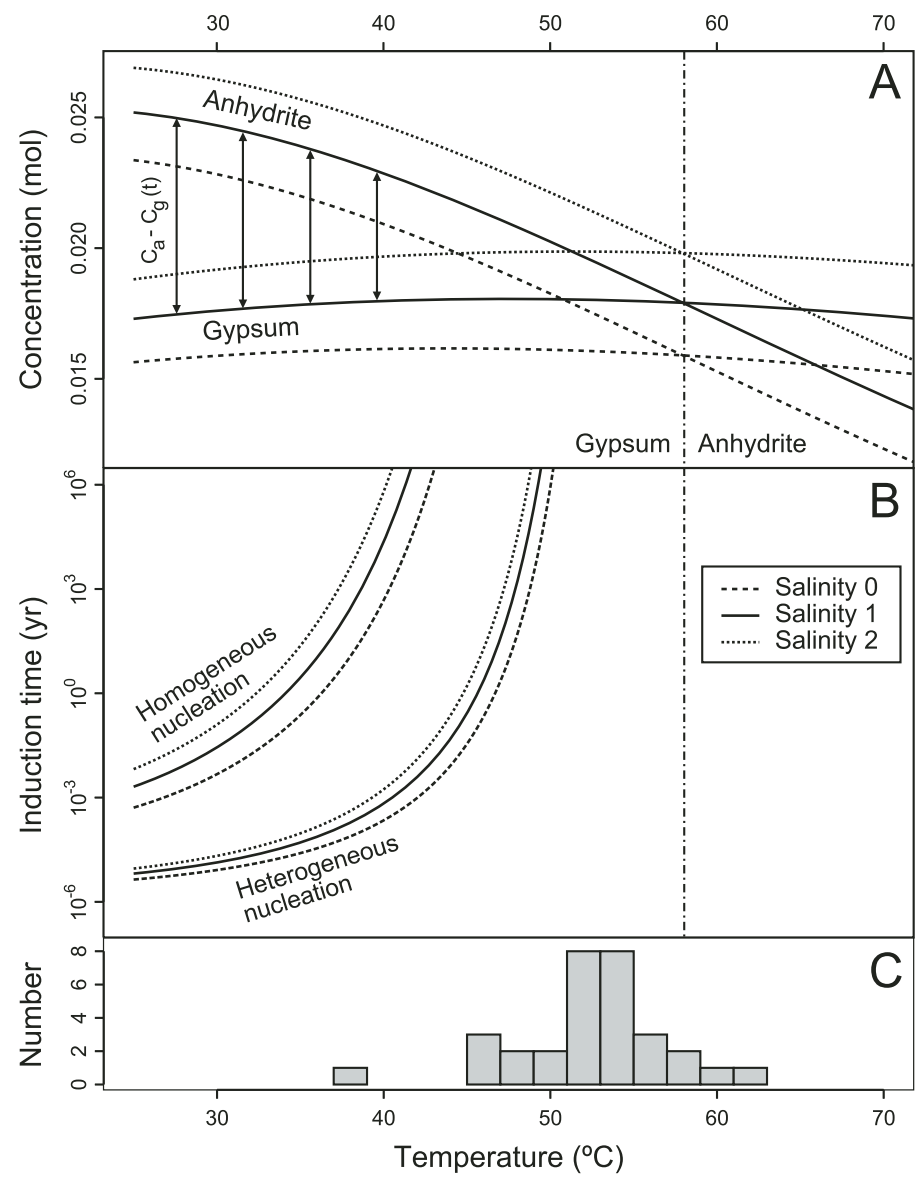

Figure 4. A: Variation of anhydrite and gypsum solubility with temperature for three different values of salinity: (0) for pure calcium sulfate solutions; (1) for salinity equal to and (2) twice that found in present-day water collected at Naica mine. B: Induction time for homogeneous and heterogeneous nucleation calculated for supersaturated solutions forming by differences in solubility between anhydrite and gypsum at different temperatures. C: Homogenization temperatures of $\mathbf{3 1}$ fluid inclusions showing actual temperature of growth.

which the solubility of anhydrite equals that of gypsum. (3) Giant selenite crystals grew from low-salinity solutions with isotopic compositions compatible with those formed by dissolving the anhydrite found in the mine. (4) Gypsum nucleation kinetics imply induction times longer than $1 \mathrm{~m} . \mathrm{y}$. for the typical temperature $\left(54^{\circ} \mathrm{C}\right)$ and $\sim 1 \mathrm{k} . \mathrm{y}$. for the lowertemperature episodes (down to $47^{\circ} \mathrm{C}$ ). This mechanism provides a level of supersaturation that is not only small and sustained over time, but is also virtually free of fluctuations (even small amplitude ones).

It can be predicted that other caves with similar or even larger selenite crystals exist among the tangle of underground galleries in the Naica mine area. They may constitute one of the oddest locations of the mineral world and are worthy of preservation; however, there are two problems that can be envisaged for that task. The cave must be kept wet and hot, but equally important is the development of a method to maintain the integrity of the long beams that bend and break once the buoyancy support of the cave water is lost. The second problem is in the long term but more critical: unless water pumping continues after mining, the caves will be again flooded to their natural state. According to the proposed mechanism, the selenite crystals may well start to grow again, but they will be hidden for future generations.
ACKNOWLEDGMENTS

We gratefully acknowledge Compañía Peñoles for the facilities provided during the field studies performed in the Naica mine, and the Ministerio de Educación y Ciencia of Spain for financial support.

\section{REFERENCES CITED}

Bakker, R.J., 2003, Package FLUIDS 1. New computer programs for the analysis of fluid inclusion data and for modelling bulk fluid properties: Chemical Geology, v. 194, p. 3-23, doi: 10.1016/S0009-2541(02)00268-1.

Blount, C.W., and Dickson, F.W., 1973, Gypsum-anhydrite equilibria in systems $\mathrm{CaSO}_{4}-\mathrm{H}_{2} \mathrm{O}$ and $\mathrm{CaSO}_{4}-\mathrm{NaCl}-\mathrm{H}_{2} \mathrm{O}$ : American Mineralogist, v. 58, p. 323-331.

Bodnar, R.J., 1993, Revised equation and table for determining the freezing point depression of $\mathrm{H}_{2} \mathrm{O}-\mathrm{NaCl}$ solutions: Geochimica et Cosmochimica Acta, v. 57, p. 683-684, doi: 10.1016/0016-7037(93)90378-A.

Butler, G.P., 1973, Strontium geochemistry of modern and ancient calcium sulphate minerals, in Purser, B.H., ed., The Persian Gulf: Berlin, SpringerVerlag, p. 423-452.

Erwood, R.J., Kesler, S.E., and Cloke, P.L., 1979, Compositionally distinct, saline hydrothermal solutions, Naica Mine, Chihuahua, Mexico: Economic Geology and Bulletin of the Society of Economic Geologists, v. 74, p. $95-108$.

Foshag, W., 1927, The selenite caves of Naica, Mexico: American Mineralogist, v. 12 , p. $252-256$.

García-Guinea, J., Morales, S., Delgado, A., Recio, C., and Calahorra, J.M., 2002, Formation of gigantic gypsum crystals: Geological Society [London] Journal, v. 159 , p. 347-350.

Hardie, L.A., 1967, The gypsum-anhydrite equilibrium at one atmosphere pressure: American Mineralogist, v. 52, p. 171-200.

He, S., Oddo, J.E., and Tomson, M.B., 1994, The nucleation kinetics of calcium sulfate dihydrate in $\mathrm{NaCl}$ solutions up to $6 \mathrm{~m}$ and $90^{\circ} \mathrm{C}$ : Journal of Colloid and Interface Science, v. 162, p. 297-303, doi: 10.1006/jcis.1994.1042.

Lancia, A., Musmarra, D., and Prisciandaro, M., 1999, Measurement of the induction period for calcium sulfate dihydrate precipitation: American Institute of Chemical Engineers Journal, v. 45, p. 390-397.

Lang, J.R., 1995, A geological evaluation of the Naica deposit, Chihuahua, Mexico: Internal Report of Compañia Fresnillo, Mexico, 109 p.

Marín Herrera, B.R., Vogel González, F., and Echegoyén Guzmán, R., 2006, Las megaselenitas del distrito minero de Naica, Chihuahua, una ocurrencia mineralógica anómala: Boletín de Mineralogía, v. 17, p. 139-148.

Megaw, P.K.M., Ruiz, J., and Titley, S.R., 1988, High-temperature, carbonatehosted $\mathrm{Pb}-\mathrm{Zn}-\mathrm{Ag}(\mathrm{Cu})$ deposits of northern Mexico: Economic Geology and Bulletin of the Society of Economic Geologists, v. 83, p. 1856-1885.

Mullin, J.W., 1993, Crystallization (third edition): Oxford, ButterworthHeinemann, $527 \mathrm{p}$.

Palache, C., 1932, The largest crystals: American Mineralogist, v. 17, p. 362-363.

Parkhurst, D.L., and Appelo, C.A.J., 2003, PHREEQC—A hydrogeochemical transport model: http://wwwbrr.cr.usgs.gov/projects/GWC_coupled/ phreeqc/index.html (September 2006).

Partridge, E.P., and White, A.H., 1929, The solubility of calcium sulfate from 0 to $200^{\circ}$ : American Chemical Society Journal, v. 51 , p. 360-370, doi: $10.1021 / \mathrm{ja} 01377 \mathrm{a} 003$.

Polyak, V.J., and Güven, N., 1996, Alunite, natroalunite and hydrated halloysite in Carlsbad Cavern and Lechuguilla Cave, New Mexico: Clays and Clay Minerals, v. 44, p. 843-850, doi: 10.1346/CCMN.1996.0440616.

Posnjak, E., 1938, The system $\mathrm{CaSO}_{4}-\mathrm{H}_{2} \mathrm{O}$ : American Journal of Science, v. 235A, p. 247-272.

Rickwood, P.C., 1981, The largest crystals: American Mineralogist, v. 66, p. 885-907.

Stone, J.G., 1959, Ore genesis in the Naica District, Chihuahua, Mexico: Economic Geology and Bulletin of the Society of Economic Geologists, v. 54, p. $1002-1034$.

Thode, H.G., and Monster, J., 1965, Sulfur-isotope geochemistry of petroleum, evaporites, and ancient seas, in Young, A., and Galley, J.E., eds., Fluids in subsurface environments: American Association of Petroleum Geologists Memoir 4, p. 367-377.

Turner, J.S., 1985, Multicomponent convection: Annual Review of Fluid Mechanics, v. 17, p. 11-44, doi: 10.1146/annurev.fl.17.010185.000303.

Manuscript received 25 September 2006

Revised manuscript received 3 December 2006

Manuscript accepted 7 December 2006

Printed in USA 